\title{
Synthesis of Magnesium Oxide Nanoplates and Their Application in Nitrogen Dioxide and Sulfur Dioxide Adsorption
}

\author{
Thi Hai Yen Duong, ${ }^{1}$ Thanh Nhan Nguyen ${ }^{D},{ }^{1}$ Ho Thi Oanh $\mathbb{D}^{1,2}$ Tuyet Anh Dang Thi, ${ }^{1,2}$ \\ Le Nhat Thuy Giang, ${ }^{1,2}$ Hoang Thi Phuong, ${ }^{1}$ Nguyen Tuan Anh (D), Ba Manh Nguyen (D), \\ Vinh Tran Quang $\mathbb{D},{ }^{1,2}$ Giang Truong Le, ${ }^{1,2}$ and Tuyen Van Nguyen $\mathbb{D}^{1,2}$ \\ ${ }^{1}$ Institute of Chemistry, Vietnam Academy of Science and Technology, 18 Hoang Quoc Viet, Cau Giay, Hanoi, Vietnam \\ ${ }^{2}$ Graduate University of Science and Technology, Vietnam Academy of Science and Technology, 18 Hoang Quoc Viet, \\ Cau Giay, Hanoi, Vietnam
}

Correspondence should be addressed to Tuyen Van Nguyen; ngvtuyen@hotmail.com

Received 15 March 2019; Revised 20 April 2019; Accepted 22 April 2019; Published 26 May 2019

Guest Editor: Thanh-Dong Pham

Copyright (c) 2019 Thi Hai Yen Duong et al. This is an open access article distributed under the Creative Commons Attribution License, which permits unrestricted use, distribution, and reproduction in any medium, provided the original work is properly cited.

In this research, nanostructured magnesium oxide was synthesized through the sol-gel calcination or hydrothermal calcination method using various surfactants. The X-ray diffraction pattern of the materials confirmed that all the prepared magnesium oxide samples were single phase without any impurity. The scanning electron microscopy images and specific surface area values showed that sodium dodecyl sulfate was the most suitable surfactant for the synthesis of magnesium oxide nanoplates with the diameter of $40-60 \mathrm{~nm}$, the average thickness of $5 \mathrm{~nm}$, and a specific surface area of $126 \mathrm{~m}^{2} / \mathrm{g}$. This material was utilized for nitrogen dioxide and sulfur dioxide adsorption under ambient condition. The saturated adsorption capacities of magnesium oxide were $174 \mathrm{mg} / \mathrm{g}$ for nitrogen dioxide and $160 \mathrm{mg} / \mathrm{g}$ for sulfur dioxide, making the magnesium oxide nanoplates a promising candidate for toxic gas treatment.

\section{Introduction}

Nowadays, air pollution caused by the emission of toxic gases from human and industrial activities poses not only tremendous threats to human health but also the destructive effects to the ecosystem. Nitrogen dioxide $\left(\mathrm{NO}_{2}\right)$ and sulfur dioxide $\left(\mathrm{SO}_{2}\right)$ are criteria pollutants that have adverse impacts on the environment. Both of $\mathrm{NO}_{2}$ and $\mathrm{SO}_{2}$ are released from natural and anthropological sources including forest fires, volcanic eruptions, transportation systems, and the combustion process. While $\mathrm{NO}_{2}$ gas could be harmful to human due to cardiovascular damage and respiratory pathway $[1,2]$, $\mathrm{SO}_{2}$ gas can affect the human health with breathing problems, cardiovascular complications, bronchitis, and eyes irritation $[3,4]$. Some studies show that for every $10 \mathrm{ppb}$ increase in $\mathrm{SO}_{2}$ concentration, the risk of death increased by $0.2-2 \%$ [5]. This increasing risk requires feasible solutions to deal with. Various methods have been developed by scientists and experts including molecular sieves, membrane separation, adsorption, and catalyst [6-9]. Among them, adsorption is one of the most effective methods for toxic gas treatment owing to simple processing and regeneration at low cost. Several materials such as activated carbon, hydroxide, metal oxide, sepiolite, and metal organic frameworks (MOFs) have been widely used as effective absorbents [10-13].

During the development of nanoscience and nanotechnology, the application of inorganic nanomaterial as toxic gas adsorbents has attracted much attention because of their large specific surface area and high reactivity. Due to the economical and eco-friendly properties, nanomagnesium oxide $(\mathrm{MgO})$ is a potential adsorbent of toxic gas [14-18]. However, to the best of our knowledge, there have been very few reports using $\mathrm{MgO}$ for the adsorption of $\mathrm{NO}_{2}$ and $\mathrm{SO}_{2}$.

Nanostructured $\mathrm{MgO}$ has been synthesized by various physicochemical techniques, such as sol-gel calcination, 
chemical precipitation, and hydrothermal and microwave fabrication [19-28]. In this research, we successfully synthesized $\mathrm{MgO}$ nanoplates by sol-gel calcination and hydrothermal calcination methods. The influence of surfactant on the morphology of nanostructured $\mathrm{MgO}$ was investigated. The $\mathrm{MgO}$ nanoplates were used for $\mathrm{NO}_{2}$ and $\mathrm{SO}_{2}$ adsorption.

\section{Materials and Methods}

All chemicals were of analytical grade and directly used without further purification. Magnesium nitrate hexahydrate $\left(\mathrm{Mg}\left(\mathrm{NO}_{3}\right)_{2} \cdot 6 \mathrm{H}_{2} \mathrm{O}\right.$, 99.9\%), sodium hydroxide ( $\mathrm{NaOH}, 99.8 \%)$, polyethylene glycol (PEG 6000), cetyltrimethylammonium bromide (CTAB, 98\%), sodium dodecyl sulfate (SDS, 98.5\%), sulfur dioxide (99.9\%), and nitrogen dioxide (99.5\%) were purchased from SigmaAldrich and used without any further purification.

2.1. Synthesis of Nanostructured $\mathrm{MgO}$. Nanostructured $\mathrm{MgO}$ was prepared by the sol-gel calcination or hydrothermal calcination method $[29,30]$ described as follows.

2.2. Sol-Gel Processing. Typically, $10 \mathrm{mmol} \mathrm{Mg}\left(\mathrm{NO}_{3}\right)_{2} \cdot 6 \mathrm{H}_{2} \mathrm{O}$ $(2.56 \mathrm{~g})$ was dissolved in $250 \mathrm{ml}$ distilled water, and $0.5 \mathrm{mmol}$ surfactant (3 g PEG 6000, 0.182 g CTAB or 0.144 g SDS) was added into the magnesium nitrate solution. Then, $100 \mathrm{ml}$ $\mathrm{NaOH} 0.2 \mathrm{M}$ solution was added dropwise into this mixture and stirred vigorously until a relatively high viscosity gel was formed. The gel was stirred gently overnight and then filtered, washed several times with distilled water, and dried at $80^{\circ} \mathrm{C}$ for 4 hours before calcinating at $500^{\circ} \mathrm{C}$ for 4 hours to obtain a white solid powder.

2.3. Hydrothermal Processing. The hydrothermal process was performed in a Teflon-lined stainless steel autoclave. $10 \mathrm{mmol} \mathrm{Mg}\left(\mathrm{NO}_{3}\right)_{2} \cdot 6 \mathrm{H}_{2} \mathrm{O}(2.56 \mathrm{~g})$ was dissolved in $250 \mathrm{ml}$ distilled water, and $0.5 \mathrm{mmol}$ surfactant ( $3 \mathrm{~g}$ PEG 6000, $0.182 \mathrm{~g} \mathrm{CTAB}$ or $0.144 \mathrm{~g}$ SDS) was added into the magnesium nitrate solution. Then, $100 \mathrm{ml} \mathrm{NaOH} 0.2 \mathrm{M}$ solution was added dropwise into this mixture. Afterward, the resulting mixture was transferred into the autoclave and heated at $100^{\circ} \mathrm{C}$ for 2 hours. After cooling down to room temperature, the precipitate was collected by vacuum filtration and calcinated at $500^{\circ} \mathrm{C}$ for 4 hours to obtain a white solid powder.

2.4. Characterization of Materials. All the obtained $\mathrm{MgO}$ materials were characterized by different physicochemical techniques. The functional groups on the surface of materials were determined by Fourier-transform infrared spectroscopy (FT-IR, Thermo Fisher, USA). Phase identification was performed by the X-ray diffraction (XRD) technique, using $\mathrm{Cu} \mathrm{K} \alpha(\lambda=1.54056 \AA)$ radiation (D/max Ultima III, Rigaku, Japan). The morphology and particle size were given by scanning electron microscope (SEM, Hitachi, S-4800). The specific surface area was measured from the nitrogen adsorption/desorption at $77 \mathrm{~K}$ using the Brunauer-
Ennett-Teller (BET) method (TriStar II Plus, Micromeritics Instrument Corp, USA). The chemical composition of $\mathrm{MgO}$ material after adsorption was analyzed with energydispersive X-ray spectroscopy (SEM-EDX) (HORIBAEMAX80; Hitachi High-Technology).

2.5. Adsorption Experiments. The experiments of evaluating the $\mathrm{NO}_{2}$ and $\mathrm{SO}_{2}$ adsorption on $\mathrm{MgO}$ nanoplates were carried out under ambient temperature. $\mathrm{SO}_{2}$ or $\mathrm{NO}_{2}$ gas was mixed with nitrogen carrier gas $\left(5 \% \mathrm{SO}_{2}\right.$ or $\mathrm{NO}_{2}$ in $\mathrm{N}_{2}$ atmosphere). A glass tube reactor was loaded with $100 \mathrm{mg}$ of $\mathrm{MgO}$ powder with the pretreatment at $200^{\circ} \mathrm{C}$ for 1 hour. Then, a stream of $\mathrm{NO}_{2}$ gas or $\mathrm{SO}_{2}$ gas was supplied with a flow rate of $50 \mathrm{ml} / \mathrm{min}$. The uptake quantities were recorded as a function of time. The adsorption of $\mathrm{NO}_{2}$ and $\mathrm{SO}_{2}$ on $\mathrm{MgO}$ nanoplates were monitored by FT-IR and EDX. The $\mathrm{MgO}$ nanoplates were collected and regenerated by calcination at $500^{\circ} \mathrm{C}$ for 4 hours. The schematic diagram for $\mathrm{NO}_{2}$ and $\mathrm{SO}_{2}$ adsorption experiment is shown in Figure 1.

\section{Results and Discussion}

3.1. Characterization of Magnesium Oxide Nanoplates. In this study, three different surfactants (PEG, CTAB, and SDS) were utilized for the synthesis of $\mathrm{MgO}$ nanocrystals by solgel and hydrothermal methods. Their crystalline structures are presented in Figure 2. The most intense peaks in XRD patterns of the synthesized $\mathrm{MgO}$ samples were observed at $2 \theta$ of $37.16^{\circ}, 43.12^{\circ}$, and $62.40^{\circ}$ which were well-matched with those of JCPDS data file of standard MgO no. 78-0430 [31]. The XRD patterns of $\mathrm{MgO}$ synthesized by using different surfactants and synthesis methods were basically similar to the surfactant-free $\mathrm{MgO}$, indicating that the crystal structure of $\mathrm{MgO}$ was not affected by surfactants or synthesis methods. Furthermore, both sol-gel and hydrothermal methods produced $\mathrm{MgO}$ crystal with single phase.

The morphology of $\mathrm{MgO}$ samples is illustrated in Figures 3 and 4. BET specific surface area values of nano-MgO are shown in Table 1. Evidently, surfactant-free $\mathrm{MgO}$ samples exhibited undefined morphology and high aggregation.

Among the three surfactants, PEG showed less influence in controlling the size and morphology of $\mathrm{MgO}$ nanoplates. In addition, $\mathrm{MgO}$ materials synthesized using this surfactant have relatively low surface areas $\left(98 \mathrm{~m}^{2} / \mathrm{g}\right.$ for the sol-gel method and $110 \mathrm{~m}^{2} / \mathrm{g}$ for the hydrothermal method). In contrast, SDS was a suitable surfactant for the formation of $\mathrm{MgO}$ nanoplates with well-defined morphology and high surface area $\left(115 \mathrm{~m}^{2} / \mathrm{g}\right.$ for sol-gel method and $126 \mathrm{~m}^{2} / \mathrm{g}$ for hydrothermal method) (Figure 5). This phenomenon might be explained by the electrostatic interaction between surfactants and $\mathrm{MgO}$ surface. The nonionic nature of PEG does not allow effective interaction with positively charged $\mathrm{MgO}$ surface while the negatively charged SDS interacts effectively with the surface of $\mathrm{MgO}$. Interestingly, $\mathrm{MgO}$ samples synthesized by the hydrothermal method had smaller average size and higher surface area compared with the samples prepared by the sol-gel method. There are two possible 


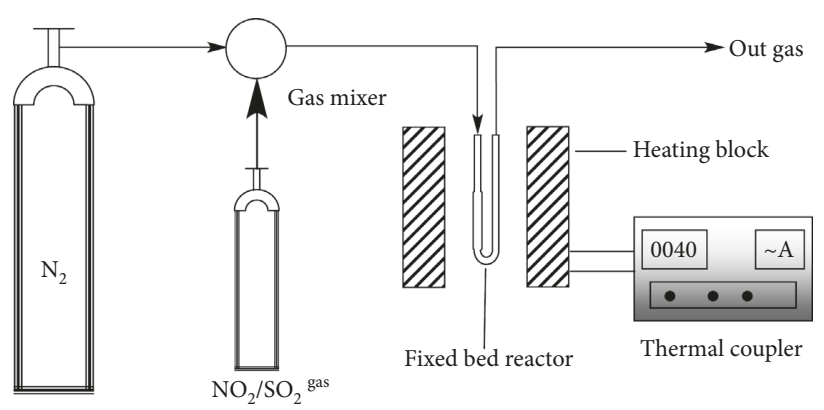

FIgURE 1: Schematic diagram of the experimental setup for $\mathrm{NO}_{2}$ and $\mathrm{SO}_{2}$ adsorptions.

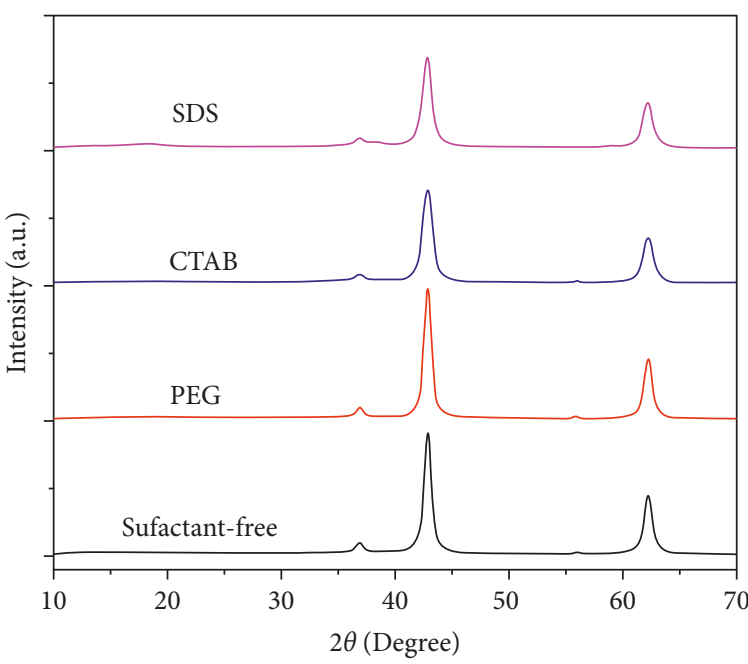

(a)

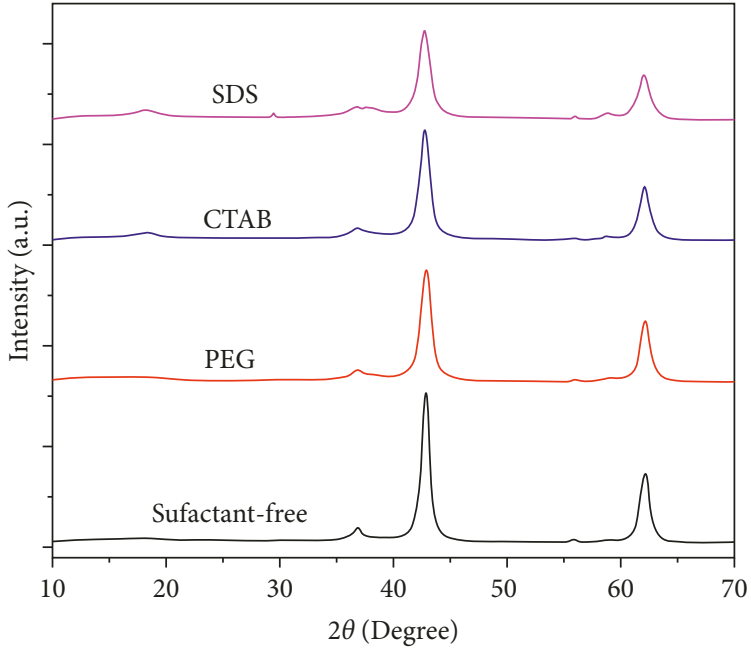

(b)

FIGURE 2: XRD patterns of nano-MgO synthesized by (a) the sol-gel method and (b) the hydrothermal method.

reasons for these higher surface areas. Firstly, during the hydrothermal process, the generating and loss of water molecules between adjacent layers of hydroxyl ions create defects, intercrystallite channels, and cracks inside the structure of $\mathrm{MgO}$, which increase the surface area and porosity of the material [30]. Secondly, when increasing temperature suddenly, the formation of nucleations is facilitated which results in the decline of precursor concentration and hence, crystals are formed with smaller size. Due to the highest surface area and good morphology, the $\mathrm{MgO}$ nanoplate material synthesized by hydrothermal method using SDS was chosen for the adsorption of $\mathrm{NO}_{2}$ and $\mathrm{SO}_{2}$ gases.

3.2. Investigation of Adsorption Ability of the Material. Fourier-transform infrared spectroscopy was employed to determine the presence of $\mathrm{NO}_{2}$ on the surface of $\mathrm{MgO}$ (Figure 6(a)). It was shown that after 10 min of adsorption, a new peak appeared at $1384 \mathrm{~cm}^{-1}$ which is assigned for $\mathrm{NO}_{3}^{-}$ vibration [32]. The appearance of $\mathrm{NO}_{3}{ }^{-}$is explained by the interaction between $\mathrm{NO}_{2}$ and the metal sites of $\mathrm{MgO}$ which facilitates the dissociation of $\mathrm{NO}_{2}$ into $\mathrm{NO}_{3}{ }^{-}$and $\mathrm{NO}[32,33]$ :

$$
2 \mathrm{NO}_{2} \longrightarrow \mathrm{N}_{2} \mathrm{O}_{4} \longrightarrow \mathrm{NO}^{+}+\mathrm{NO}_{3}^{-}
$$

The intensity of this peak increased with the increase of the adsorption time, indicating higher loading of $\mathrm{NO}_{2}$ on $\mathrm{MgO}$ nanoplates. Figure 6(b) presents the results of the adsorption experiment for $\mathrm{NO}_{2}$. The uptake rate increased rapidly during the first $20 \mathrm{~min}$ with the adsorbed amount of $111 \mathrm{mg}_{\mathrm{NO}_{2}} / \mathrm{g}_{\mathrm{MgO}}$. After $60 \mathrm{~min}$ of adsorption, the adsorbed $\mathrm{NO}_{2}$ reached $89 \%$ of the maximum capacity (the adsorption equilibrium was achieved after $180 \mathrm{~min}$ of adsorption with the uptake value of $\left.174 \mathrm{mg}_{\mathrm{NO}_{2}} / \mathrm{g}_{\mathrm{MgO}}\right)$. The EDX results (Figure 6(c)) verified the existence of $N$ elements on $\mathrm{MgO}$ nanoplates with 4.55 wt.\%, corresponding to the $\mathrm{NO}_{2}$ adsorption of $176 \mathrm{mg} / \mathrm{g}_{\mathrm{MgO}}$, which was in agreement with the adsorption result. The SEM image (inset in Figure 6(c)) illustrated the surface of $\mathrm{MgO}$ sample after the adsorption process without any change in comparison with the original sample. In addition, XRD patterns of $\mathrm{MgO}$ sample after 180 min of exposure to $\mathrm{NO}_{2}$ showed no difference with the initial sample (Figure 6(d)).

The results of the $\mathrm{SO}_{2}$ adsorption on $\mathrm{MgO}$ nanoplates are presented in Figure 7. Because of the number of basic sites over $\mathrm{MgO}$, a $\mathrm{SO}_{2, \text { gas }}+\mathrm{MgO} \longrightarrow \mathrm{MgSO}_{3}$ reaction could be expected [33,34]. The presence of $\mathrm{SO}_{2}$ on the $\mathrm{MgO}$ surface was affirmed by the broadband at $984 \mathrm{~cm}^{-1}$ [35] in the IR spectrum (Figure $7(\mathrm{a})$ ). This band enlarged along the 


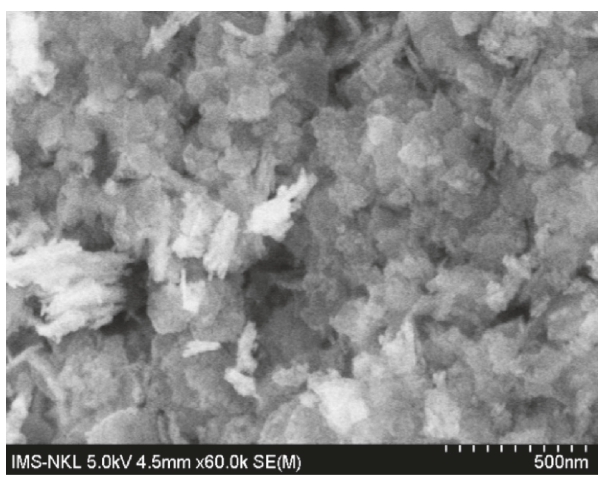

(a)

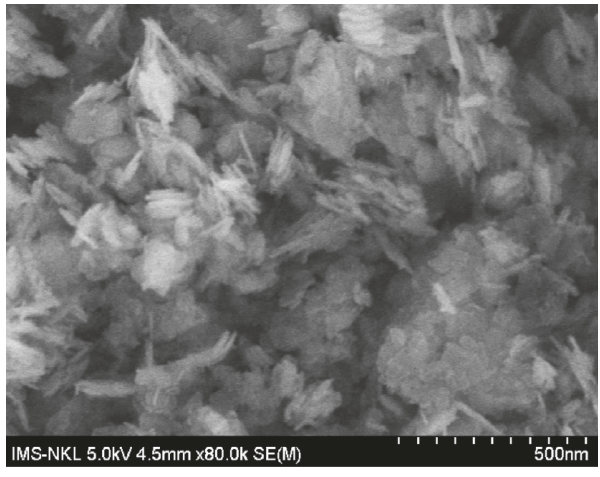

(c)

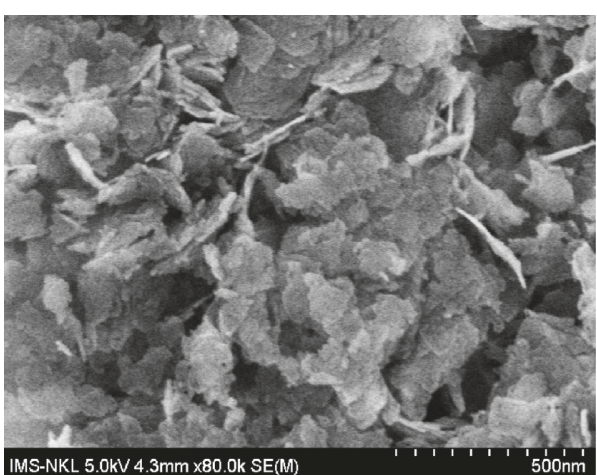

(b)

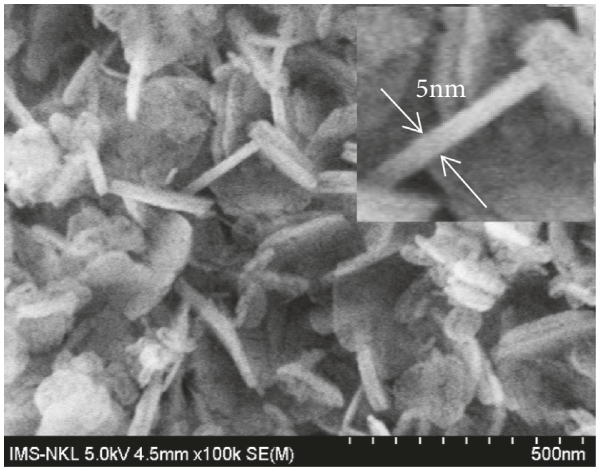

(d)

Figure 3: SEM images of nano-MgO prepared by the sol-gel method using different surfactants: (a) surfactant-free, (b) PEG, (c) CTAB, and (d) SDS.

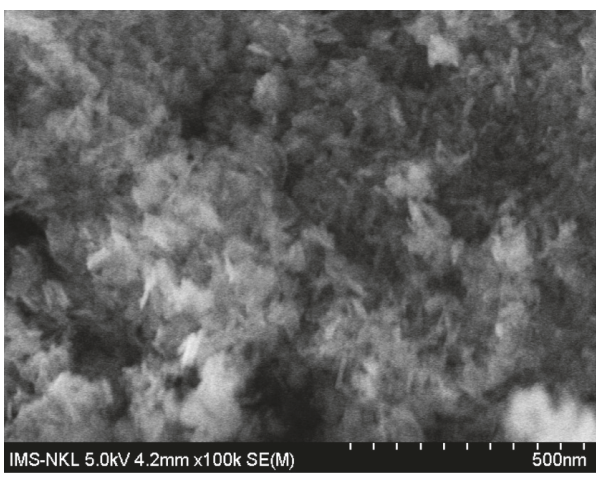

(a)

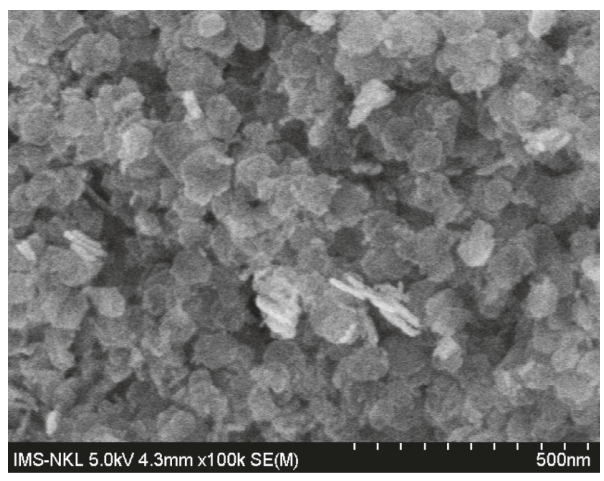

(c)

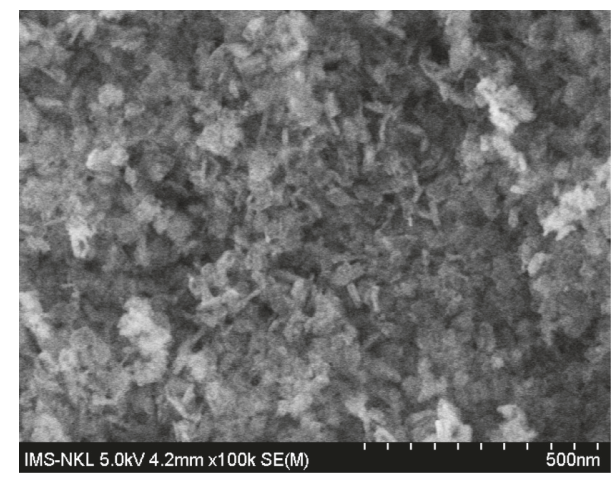

(b)

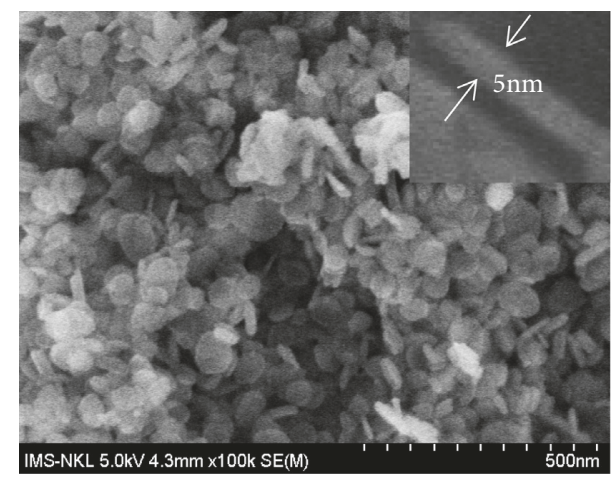

(d)

FIGURE 4: SEM images of nano-MgO prepared by the hydrothermal method using different surfactants: (a) surfactant-free, (b) PEG, (c) CTAB, and (d) SDS. 
TABLE 1: BET specific surface area values of nano-MgO synthesized by using different surfactants.

\begin{tabular}{lccccc}
\hline & Method & Surfactant-free & PEG & CTAB & SDS \\
\hline \multirow{2}{*}{$S_{\mathrm{BET}}\left(\mathrm{m}^{2} / \mathrm{g}\right)$} & Sol-gel & 66 & 98 & 100 & 115 \\
& Hydrothermal & 88 & 110 & 119 & 126 \\
\hline
\end{tabular}

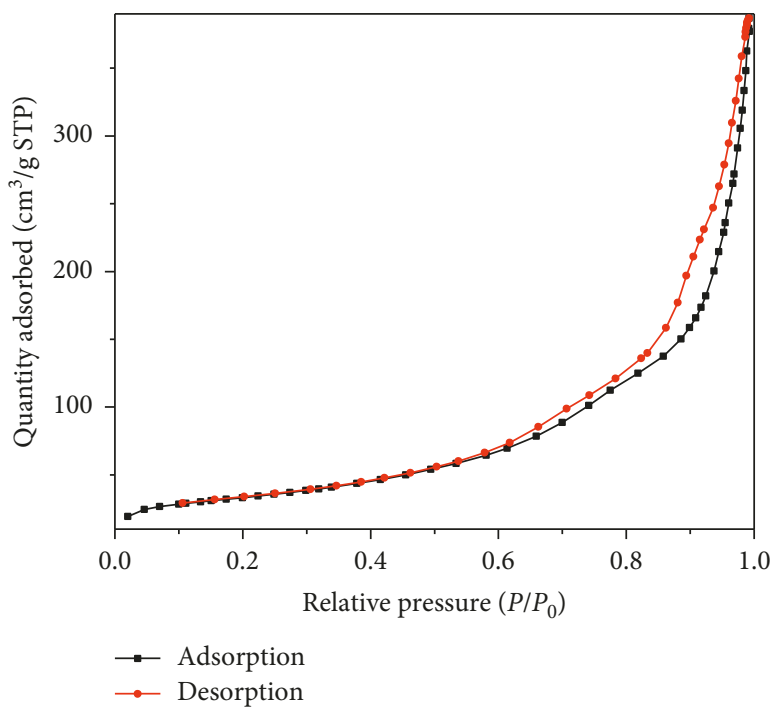

(a)

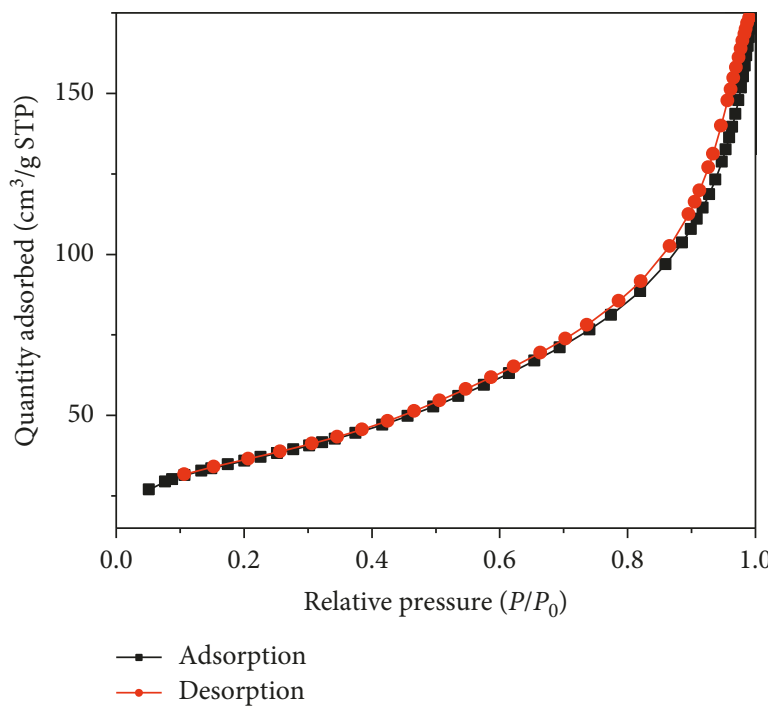

(b)

FIGURE 5: $\mathrm{N}_{2}$ adsorption/desorption isotherms of $\mathrm{MgO}$ nanoplates synthesized using SDS by (a) the sol-gel calcination method and (b) the hydrothermal calcination method.

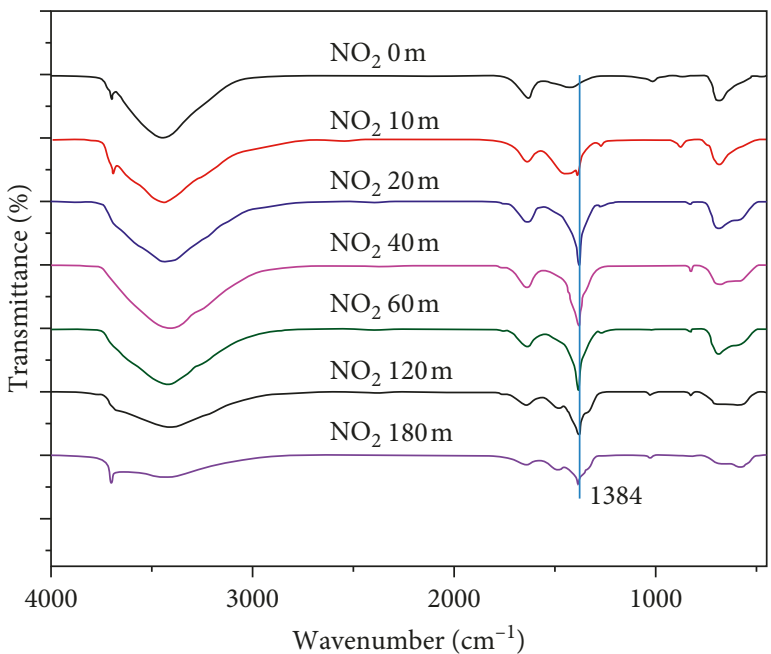

(a)

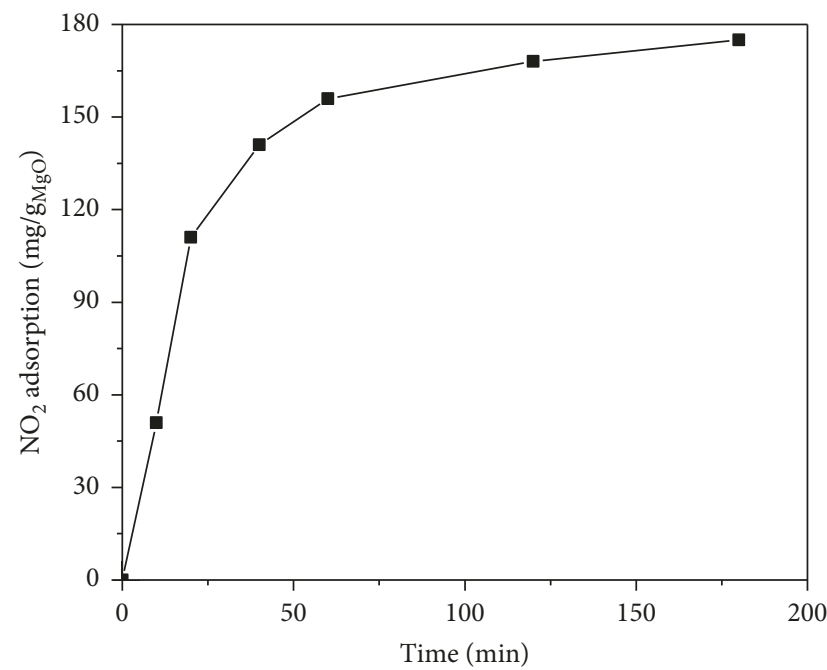

(b)

Figure 6: Continued. 


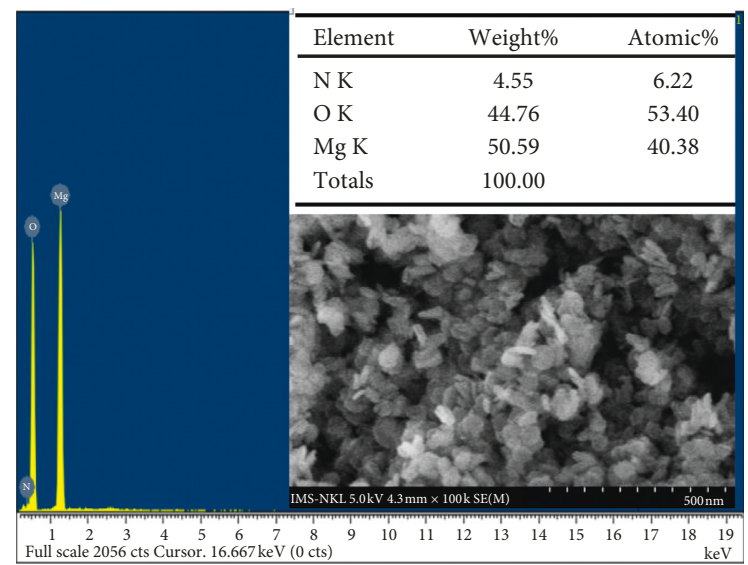

(c)

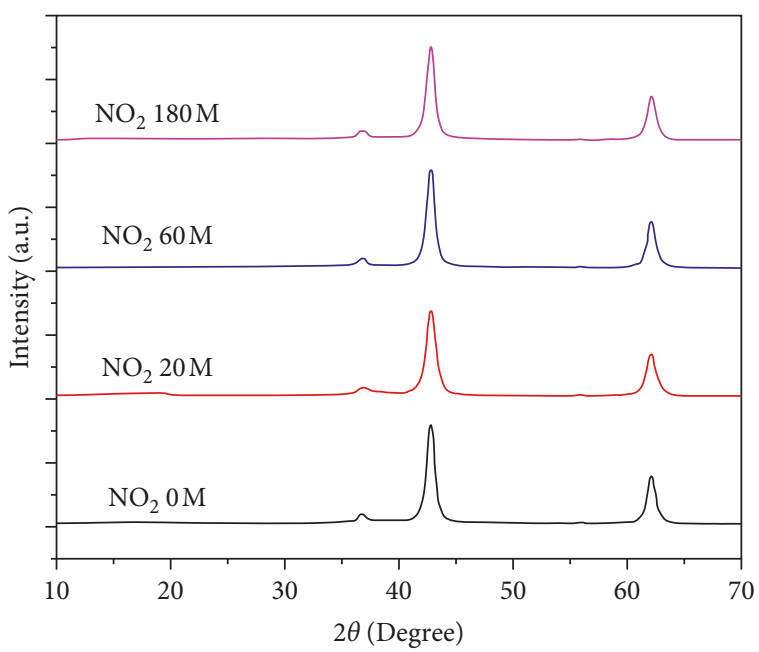

(d)

FIGURE 6: (a) FT-IR spectra of $\mathrm{MgO}$ samples after different adsorption times; (b) quantity of $\mathrm{NO}_{2}$ adsorbed on $\mathrm{MgO}$; (c) EDX spectrum and SEM image of $\mathrm{MgO}$ after $180 \mathrm{~min}$ of adsorption; (d) XRD patterns of MgO samples after different adsorption times.

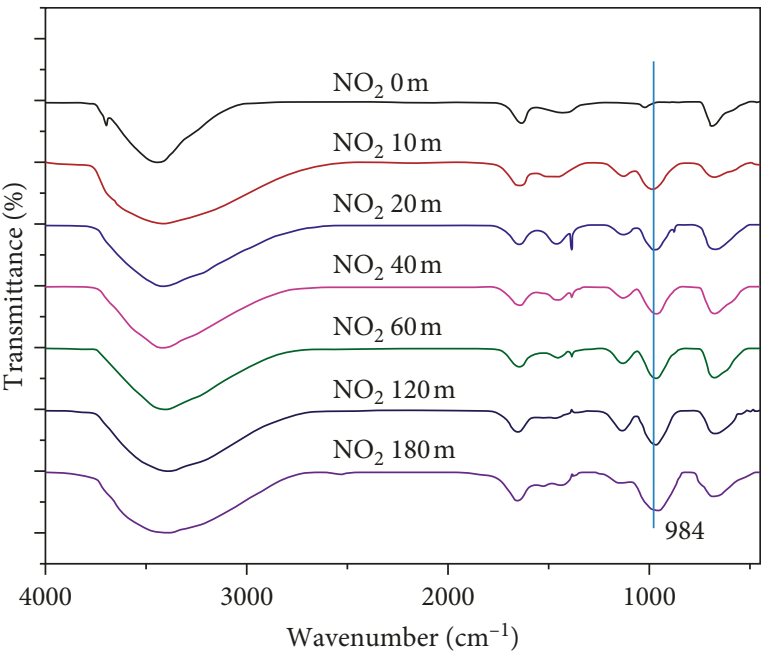

(a)

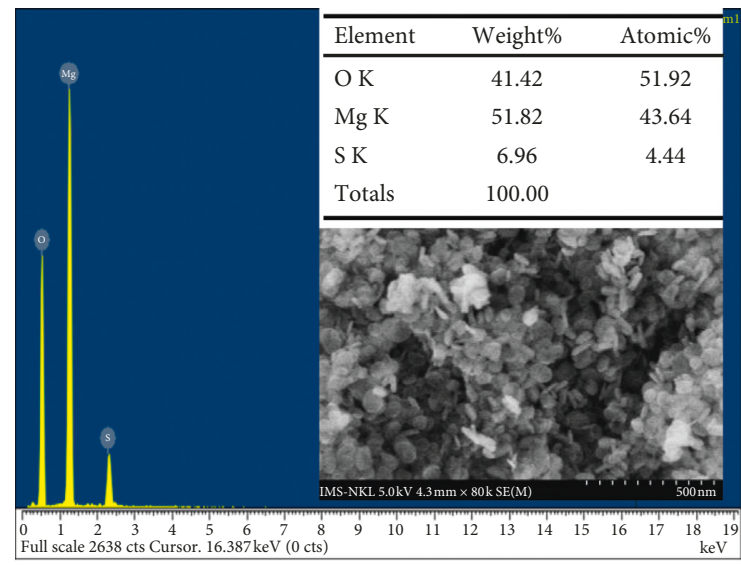

(c)

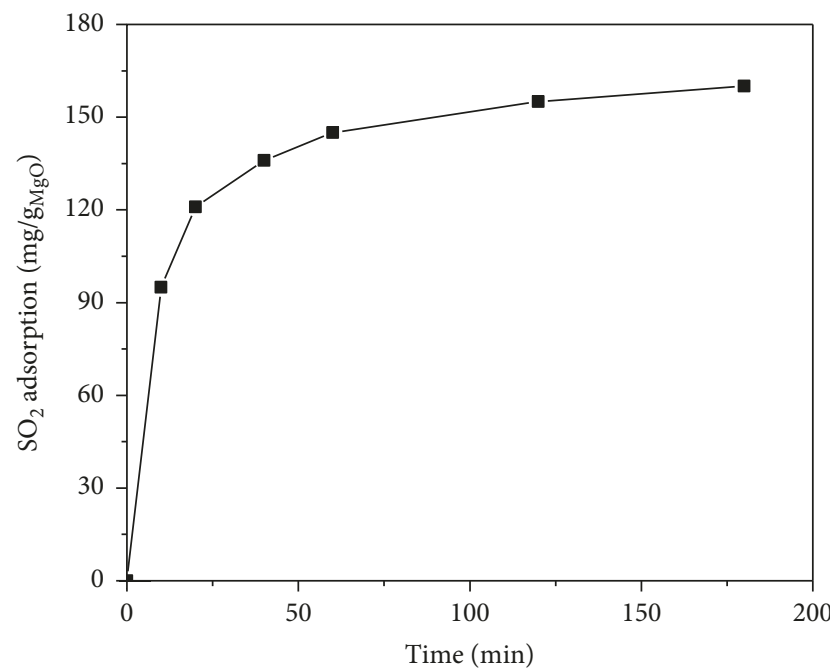

(b)

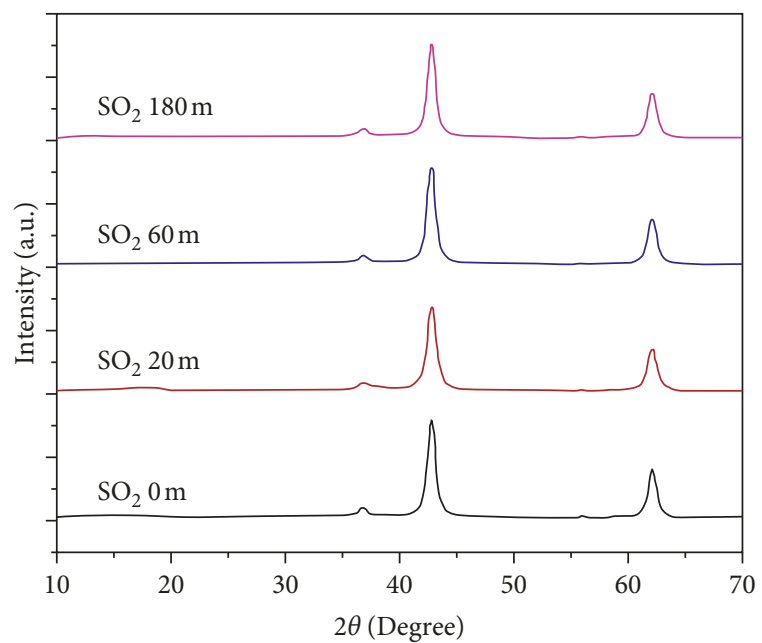

(d)

FIGURE 7: (a) FT-IR spectra of MgO samples after different adsorption times; (b) quantity of $\mathrm{SO}_{2}$ adsorbed on MgO; (c) EDX spectrum and SEM image of $\mathrm{MgO}$ after $180 \mathrm{~min}$ of adsorption; (d) XRD patterns of $\mathrm{MgO}$ samples after different adsorption times. 


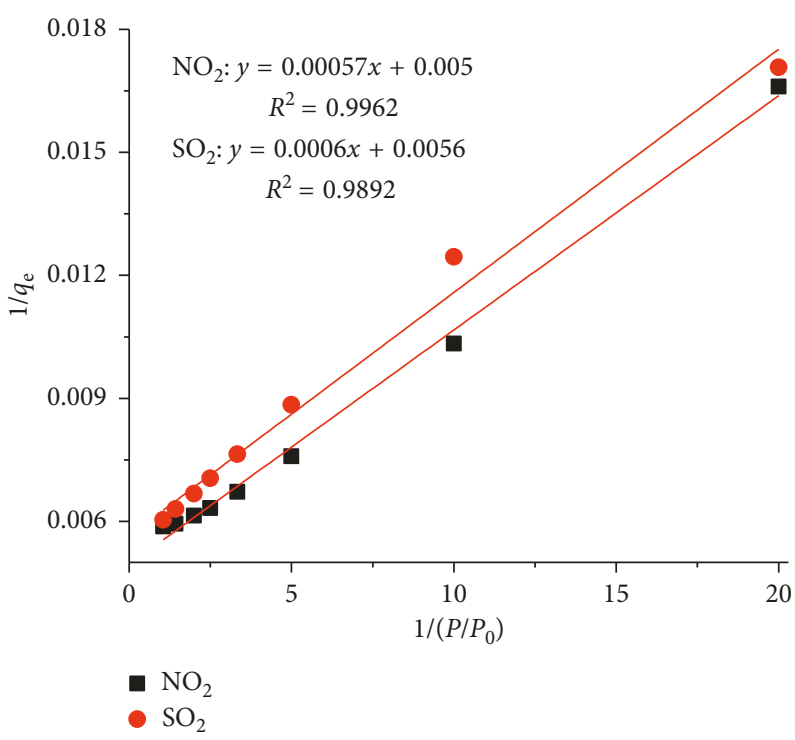

FIgURE 8: Langmuir adsorption isotherm of $\mathrm{NO}_{2}$ and $\mathrm{SO}_{2}$ over $\mathrm{MgO}$ nanoplates.

TABLE 2: $\mathrm{NO}_{2}$ and $\mathrm{SO}_{2}$ adsorption capacity of $\mathrm{MgO}$ nanoplates compares with well-known adsorbents.

\begin{tabular}{|c|c|c|c|c|c|}
\hline \multirow[t]{2}{*}{ Adsorbent } & \multirow[t]{2}{*}{ Experimental condition } & \multirow{2}{*}{$\begin{array}{l}\text { Adsorption } \\
\text { time (min) }\end{array}$} & \multicolumn{2}{|c|}{$\begin{array}{l}\text { Saturated adsorption } \\
\text { capacity }(\mathrm{mg} / \mathrm{g})\end{array}$} & \multirow[t]{2}{*}{ Reference } \\
\hline & & & $\mathrm{NO}_{2}$ & $\mathrm{SO}_{2}$ & \\
\hline $\begin{array}{l}\text { Porous media prepared from sewage } \\
\text { sludge }\left(S_{\mathrm{BET}}=21.2 \mathrm{~m}^{2} / \mathrm{g}\right)\end{array}$ & $\begin{array}{c}\text { (i) Concentration: } \\
\mathrm{NO}_{2}: 70 \mathrm{ppm}(0.007 \%) \text { in nitrogen } \\
\mathrm{SO}_{2}: 100 \mathrm{ppm}(0.01 \%) \text { in nitrogen }\end{array}$ & $\begin{array}{l}70\left(\mathrm{NO}_{2}\right) ; 100 \\
\left(\mathrm{SO}_{2}\right)\end{array}$ & $\begin{array}{c}1.12 \\
(0.0244 \mathrm{mmol} / \\
\mathrm{g})\end{array}$ & $\begin{array}{c}0.98 \\
(0.0214 \mathrm{mmol} / \\
\mathrm{g})\end{array}$ & {$[36]$} \\
\hline $\begin{array}{l}\text { Zeolite-coated porous media } \\
\left(S_{\mathrm{BET}}=13.1 \mathrm{~m}^{2} / \mathrm{g}\right)\end{array}$ & $\begin{array}{l}\text { (ii) Moisture: } 0 \% \\
\text { (iii) Adsorbent weight: } 0.55 \mathrm{~g} \\
\text { (iv) Gas flow rate: } 17000 \mathrm{ml} / \mathrm{min} \\
\text { (v) Temperature: } 25^{\circ} \mathrm{C}\end{array}$ & $\begin{array}{c}40\left(\mathrm{NO}_{2}\right) ; 65 \\
\left(\mathrm{SO}_{2}\right)\end{array}$ & $\begin{array}{l}2.08 \\
(0.0451 \mathrm{mmol} / \\
\mathrm{g})\end{array}$ & $\begin{array}{l}1.72 \\
(0.0374 \mathrm{mmol} / \\
\mathrm{g})\end{array}$ & {$[36]$} \\
\hline Activated carbon $\left(S_{\mathrm{BET}}=1077 \mathrm{~m}^{2} / \mathrm{g}\right)$ & $\begin{array}{c}\text { (i) Concentration: } \\
\mathrm{NO}_{2}: 4856 \text { ppm }(0.4856 \%) \text { in } \\
\text { nitrogen } \\
\mathrm{SO}_{2}: 1170 \text { ppm }(0.1170 \%) \text { in nitrogen } \\
\text { (relative pressure: } 2.47 \text { ) } \\
\text { (ii) Moisture: } 0 \% \\
\text { (iii) Adsorbent weight: } 1.5 \mathrm{~g} \\
\text { (iv) Gas flow rate: } 583 \mathrm{ml} / \mathrm{min} \\
\text { (v) Temperature: } 30^{\circ} \mathrm{C}\end{array}$ & 60 & $\begin{array}{c}135.70 \\
(2.95 \mathrm{mmol} / \mathrm{g})\end{array}$ & $\begin{array}{l}42.10(2.73 \\
\text { wt. } \%)\end{array}$ & {$[37]$} \\
\hline MgO nanoplates $\left(S_{\mathrm{BET}}=126 \mathrm{~m}^{2} / \mathrm{g}\right)$ & $\begin{array}{l}\text { (i) Concentration: } 5 \% \text { in nitrogen } \\
\text { (ii) Moisture: } 0 \% \\
\text { (iii) Adsorbent weight: } 0.1 \mathrm{~g} \\
\text { (iv) Gas flow rate: } 50 \mathrm{ml} / \mathrm{min} \\
\text { (v) Temperature: } 25^{\circ} \mathrm{C}\end{array}$ & 180 & 174.00 & 160.00 & $\begin{array}{l}\text { This } \\
\text { research }\end{array}$ \\
\hline
\end{tabular}

adsorption time. As shown in Figure 7(b), the amount of $\mathrm{SO}_{2}$ measured after $10 \mathrm{~min}$ reached $95 \mathrm{mg} / \mathrm{g}_{\mathrm{MgO}}$. After $60 \mathrm{~min}$, the adsorbed $\mathrm{SO}_{2}$ reached $93 \%$ of the maximum capacity (the adsorption equilibrium was achieved after $180 \mathrm{~min}$ of adsorption with the uptake value of $\left.160 \mathrm{mg} / \mathrm{g}_{\mathrm{MgO}}\right)$. The EDX spectrum (Figure 7(c)) confirmed the presence of $S$ on the $\mathrm{MgO}$ surface. The content of $S$ element was $6.96 \mathrm{wt} . \%$, corresponding to $13.92 \mathrm{wt} . \% \mathrm{SO}_{2}$ in the sample after $180 \mathrm{~min}$ of exposure. The calculated amount of $\mathrm{SO}_{2}$ was about $162 \mathrm{mg} / \mathrm{g}_{\mathrm{MgO}}$, similar to the obtained $\mathrm{SO}_{2}$ adsorption of $\mathrm{MgO}$ shown in Figure $7(\mathrm{~b})$. The SEM image (inset in Figure $7(\mathrm{c})$ ) and the XRD patterns (Figure $7(\mathrm{~d})$ ) show no change in morphology as well as the crystalline structure after 180 min of $\mathrm{SO}_{2}$ exposure compared with the original $\mathrm{MgO}$ sample, indicating the high stability of $\mathrm{MgO}$ nanoplates under the experimental condition.

The Langmuir model was used to evaluate the adsorption of $\mathrm{NO}_{2}$ and $\mathrm{SO}_{2}$ over $\mathrm{MgO}$ nanoplates. The Langmuir adsorption isotherm plots of $\mathrm{NO}_{2}$ and $\mathrm{SO}_{2}$ adsorption over $\mathrm{MgO}$ nanoplates are shown in Figure 8 . The $R^{2}$ values of 0.9892 (in the case of $\mathrm{SO}_{2}$ ) and 0.9962 (in the case of $\mathrm{NO}_{2}$ ) illustrate the fitness of the Langmuir model for the adsorption. The equilibrium adsorption capacity value $\left(q_{\mathrm{e}}\right)$ was calculated with the relative pressure $\left(p / p_{0}\right)$ value of 1 . The $q_{\mathrm{e}}$ 


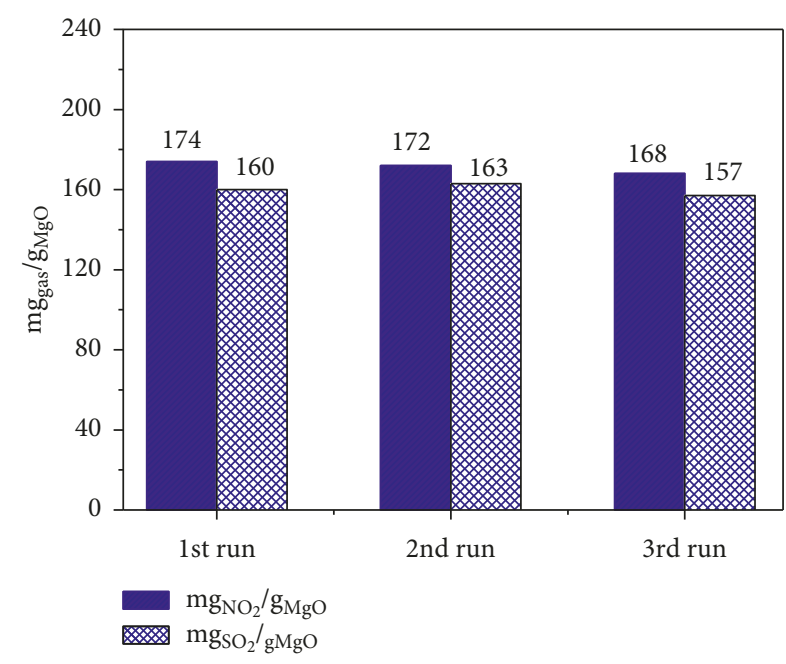

FIgURE 9: Diagram of adsorption capacity of $\mathrm{NO}_{2}$ and $\mathrm{SO}_{2}$ over $\mathrm{MgO}$ nanoplates after three cycles.

calculated values for the adsorption of $\mathrm{NO}_{2}$ and $\mathrm{SO}_{2}$ are $178.52 \mathrm{mg} / \mathrm{g}$ and $161.29 \mathrm{mg} / \mathrm{g}$, respectively. These values were similar to the obtained experimental values of $174 \mathrm{mg} / \mathrm{g}$ (in the case of $\mathrm{NO}_{2}$ ) and $160 \mathrm{mg} / \mathrm{g}$ (in the case of $\mathrm{SO}_{2}$ ). This result shows the compatibility between experimental and theoretical calculations.

Furthermore, the adsorption capacity of $\mathrm{NO}_{2}$ and $\mathrm{SO}_{2}$ over $\mathrm{MgO}$ nanoplates was compared with that of reported porous adsorbents. The adsorption capacity and experimental conditions of these materials are summarized in Table 2. Interestingly, the $\mathrm{MgO}$ nanoplates exhibited relatively higher adsorption capacity than microporous activated carbon and zeolite [36, 37].

In order to evaluate the recycle of $\mathrm{MgO}$ nanoplates, this adsorber was regenerated and reused for $\mathrm{NO}_{2}$ and $\mathrm{SO}_{2}$ adsorption. The $\mathrm{NO}_{2}$ and $\mathrm{SO}_{2}$ adsorption capacity at the third cycle only decreased 3.45 and $1.87 \%$, respectively (Figure 9). The result further confirmed the potential applicability of $\mathrm{MgO}$ nanoplates for the adsorption of $\mathrm{NO}_{2}$ and $\mathrm{SO}_{2}$.

\section{Conclusions}

To summarize, $\mathrm{MgO}$ nanoplates were well synthesized by sol-gel and hydrothermal methods using PEG, CTAB, and SDS as the morphology-controlling agents. The $\mathrm{MgO}$ nanoplates prepared by the hydrothermal method using SDS surfactant exhibited high specific surface area $\left(126 \mathrm{~m}^{2} / \mathrm{g}\right)$ and well-defined morphology of nanoplates with the diameter of 40-60 $\mathrm{nm}$ and the average thickness of $5 \mathrm{~nm}$. The adsorption experiments showed high $\mathrm{NO}_{2}$ and $\mathrm{SO}_{2}$ uptake values on $\mathrm{MgO}$ nanoplates $(174 \mathrm{mg} / \mathrm{g}$ and $160 \mathrm{mg} / \mathrm{g}$, respectively). Moreover, the $\mathrm{MgO}$ samples were highly stable under the exposure of $\mathrm{NO}_{2}$ and $\mathrm{SO}_{2}$. These results indicate that $\mathrm{MgO}$ is a potential candidate for the adsorption of toxic gases. Further work is ongoing to investigate the adsorption behavior of the material in severe condition. In addition, the kinetic and mechanism of adsorption will be studied for the future application of $\mathrm{MgO}$ nanoplates in toxic gas removal and enhancement of the performance of gas treatment on $\mathrm{MgO}$.

\section{Data Availability}

The data used to support the findings of this study are available from the corresponding author upon request.

\section{Conflicts of Interest}

The authors declare that there are no conflicts of interest regarding the publication of this paper.

\section{Acknowledgments}

This research was funded by the Vietnam Academy of Science and Technology under grant number "TĐPCCC.01/ 18-20.”

\section{References}

[1] E. Fattore, V. Paiano, A. Borgini et al., "Human health risk in relation to air quality in two municipalities in an industrialized area of northern Italy," Environmental Research, vol. 111, no. 8, pp. 1321-1327, 2011.

[2] L. Curtis, W. Rea, P. Smith-Willis, E. Fenyves, and Y. Pan, "Adverse health effects of outdoor air pollutants," Environment International, vol. 32, no. 6, pp. 815-830, 2006.

[3] Y. Omidi, G. Goudarzi, A. M. Heidari, and S. M. Daryanoosh, "Health impact assessment of short-term exposure to $\mathrm{NO}_{2}$ in Kermanshah, Iran using AirQ mode," Environmental Health Engineering and Management, vol. 3, no. 2, pp. 91-97, 2016.

[4] M. L. Williams, R. W. Atkinson, H. R. Anderson, and F. J. Kelly, "Associations between daily mortality in London and combined oxidant capacity, ozone and nitrogen dioxide," Air Quality, Atmosphere \& Health, vol. 7, no. 4, pp. 407-414, 2014.

[5] E. Burt, P. Orris, and S. Buchanan, Scientific Evidence of Health Effects from Coal Use in Energy Generation, School of Public Health, University of Illinois and Health Care Without Harm, Chicago, IL, USA, 2013.

[6] D. Plee, "Organic compounds adsorption on molecular sieves in gas phase-a comparison with activated carbons," Environmental Science, vol. 61, pp. 349-357, 1994.

[7] R. W. Baker and B. T. Low, "Gas separation membrane materials: a perspective," Macromolecules, vol. 47, no. 20, pp. 6999-7013, 2014.

[8] G. Itskos, N. Koukouzas, C. Vasilatos, I. Megremi, and A. Moutsatsou, "Comparative uptake of toxic elements from aqueous media by the different particle-size-fractions of fly ash," Journal of Hazardous Materials, vol. 183, no. 1-3, pp. 787-792, 2010.

[9] H. Yang, Z. Xu, M. Fan et al., "Progress in carbon dioxide separation and capture: a review," Journal of Environmental Sciences, vol. 20, no. 1, pp. 14-27, 2008.

[10] C. Lu, H. Bai, B. Wu, F. Su, and J. F. Hwang, "Comparative study of $\mathrm{CO}_{2}$ capture by carbon nanotubes, activated carbons, and zeolites," Energy \& Fuels, vol. 22, no. 5, pp. 3050-3056, 2008.

[11] L. G. Neal, J. L. Haslbeck, and H. P. Tseng, "Sorbent for removing nitrogen oxides, sulfur oxides and hydrogen sulfide from gas streams," U.S. Patent 4, 755, 499, 1988. 
[12] J. A. Delgado, M. A. Uguina, J. L. Sotelo, B. Ruíz, and M. Rosário, "Carbon dioxide/methane separation by adsorption on sepiolite," Journal of Natural Gas Chemistry, vol. 16, no. 3, pp. 235-243, 2007.

[13] I. Ahmed and S. H. Jhung, "Composites of metal-organic frameworks: preparation and application in adsorption," Materials Today, vol. 17, no. 3, pp. 136-146, 2014.

[14] C. Liang, T. Sasaki, Y. Shimizu, and N. Koshizaki, "Pulsedlaser ablation of $\mathrm{Mg}$ in liquids: surfactant-directing nanoparticle assembly for magnesium hydroxide nanostructures," Chemical Physics Letters, vol. 389, no. 1-3, pp. 58-63, 2004.

[15] Z. Camtakan, S. A. Erenturk, and S. D. Yusan, "Magnesium oxide nanoparticles: preparation, characterization, and uranium sorption properties," Environmental Progress \& Sustainable Energy, vol. 31, no. 4, pp. 536-543, 2012.

[16] J. Y. Park, Y. J. Lee, and K. W. Jun, "Chemical synthesis and characterization of highly oil dispersed MgO nanoparticles," Journal of Industrial and Engineering Chemisty, vol. 12, pp. 882-887, 2006.

[17] V. Štengl, S. Bakardjieva, M. Mařrkková, P. Bezdička, and J. Šubrt, "Magnesium oxide nanoparticles prepared by ultrasound enhanced hydrolysis of Mg-alkoxides," Materials Letters, vol. 57, no. 24-25, pp. 3998-4003, 2003.

[18] J. C. Yu, A. Xu, L. Zhang, R. Song, and L. Wu, "Synthesis and characterization of porous magnesium hydroxide and oxide nanoplates," Journal of Physical Chemistry B, vol. 108, no. 1, pp. 64-70, 2004.

[19] L. Wang, J. Wang, and D. den Engelsen, "Controlled synthesis of magnesium oxide nanoparticles for dye adsorption," Journal of Nanoelectronics and Optoelectronics, vol. 12, no. 5, pp. 512-517, 2017.

[20] G. Yuan, J. Zheng, C. Lin, X. Chang, and H. Jiang, "Electrosynthesis and catalytic properties of magnesium oxide nanocrystals with porous structures," Materials Chemistry and Physics, vol. 130, no. 1-2, pp. 387-391, 2011.

[21] P. Ouraipryvan, T. Sreethawong, and S. Chavadej, "Synthesis of crystalline $\mathrm{MgO}$ nanoparticle with mesoporous-assembled structure via a surfactant-modified sol-gel process," Materials Letters, vol. 63, no. 21, pp. 1862-1865, 2009.

[22] M. Rezaei, M. Khajenoori, and B. Nematollahi, "Preparation of nanocrystalline $\mathrm{MgO}$ by surfactant assisted precipitation method," Materials Research Bulletin, vol. 46, no. 10, pp. 1632-1637, 2011

[23] Z. Wei, H. Qi, P. Ma, and J. Bao, "A new route to prepare magnesium oxide whisker," Inorganic Chemistry Communications, vol. 5, no. 2, pp. 147-149, 2002.

[24] L. Yan, J. Zhuang, X. Sun, Z. Deng, and Y. Li, "Formation of rod-like $\mathrm{Mg}(\mathrm{OH})_{2}$ nanocrystallites under hydrothermal conditions and the conversion to $\mathrm{MgO}$ nanorods by thermal dehydration," Materials Chemistry and Physics, vol. 76, no. 2, pp. 119-122, 2002.

[25] Z. Zhao, H. Dai, Y. Du, J. Deng, L. Zhang, and F. Shi, "Solvoor hydrothermal fabrication and excellent carbon dioxide adsorption behaviors of magnesium oxides with multiple morphologies and porous structures," Materials Chemistry and Physics, vol. 128, no. 3, pp. 348-356, 2011.

[26] L. Kumari, W. Z. Li, C. H. Vannoy, R. M. Leblanc, and D. Z. Wang, "Synthesis, characterization and optical properties of $\mathrm{Mg}(\mathrm{OH})_{2}$ micro-/nanostructure and its conversion to MgO," Ceramics International, vol. 35, no. 8, pp. 3355-3364, 2009.

[27] G. Gao and L. Xiang, "Emulsion-phase synthesis of honeycomb-like $\mathrm{Mg}_{5}(\mathrm{OH})_{2}\left(\mathrm{CO}_{3}\right)_{4} \cdot 4 \mathrm{H}_{2} \mathrm{O}$ micro-spheres and subsequent decomposition to $\mathrm{MgO}$," Journal of Alloys and Compounds, vol. 495, no. 1, pp. 242-246, 2010.

[28] T. X. Phuoc, B. H. Howard, D. V. Martello, Y. Soong, and M. K. Chyu, "Synthesis of $\mathrm{Mg}(\mathrm{OH})_{2}, \mathrm{MgO}$, and $\mathrm{Mg}$ nanoparticles using laser ablation of magnesium in water and solvents," Optics and Lasers in Engineering, vol. 46, no. 11, pp. 829-834, 2008.

[29] R. Wahab, S. G. Ansari, M. A. Dar, Y. S. Kim, and H. S. Shin, "Synthesis of magnesium oxide nanoparticles by sol-gel process," Materials Science Forum, vol. 558-559, pp. 983986, 2007.

[30] Y. Ding, G. Zhang, H. Wu, B. Hai, L. Wang, and Y. Qian, "Nanoscale magnesium hydroxide and magnesium oxide powders: control over size, shape, and structure via hydrothermal synthesis," Chemistry of Materials, vol. 13, no. 2, pp. 435-440, 2001.

[31] M. Badr-Mohammadia, I. Mobasherpoura, E. Marzban Rada, and G. Mortazavic, "Synthesis of cubic MgO nanostructure by an easy hydrothermal-calcinations method," Journal of Ceramic Processing Research, vol. 15, no. 2, pp. 88-92, 2014

[32] C. Sedlmair, B. Gil, K. Seshan, A. Jentys, and J. A. Lercher, "An in situ IR study of the NOx adsorption/reduction mechanism on modified Y zeolites," Physical Chemistry Chemical Physics, vol. 5, no. 9, pp. 1897-1905, 2003.

[33] J. A. Rodriguez, T. Jirsak, L. González, J. Evans, M. Pérez, and A. Maiti, "Reaction of $\mathrm{SO}_{2}$ with pure and metal-doped $\mathrm{MgO}$ : basic principles for the cleavage of S-O bonds," Journal of Chemical Physics, vol. 115, no. 23, pp. 10914-10926, 2001.

[34] M. Waqif, A. M. Saad, M. Bensitel, J. Bachelier, O. Saur, and J.-C. Lavalley, "Comparative study of $\mathrm{SO}_{2}$ adsorption on metal oxides," Journal of the Chemical Society, Faraday Transactions, vol. 88, no. 19, pp. 2931-2936, 1992.

[35] F. A. Miller and C. H. Wilkins, "Infrared spectra and characteristic frequencies of inorganic ions," Analytical Chemistry, vol. 24, no. 8, pp. 1253-1294, 1952.

[36] Y. S. Yoo, E. Z. Park, H. J. Ban, and H. J. Chae, "Removal of $\mathrm{NO}_{2}$ and $\mathrm{SO}_{2}$ using porous media made from sewage sludge removal," Materials Science Forum, vol. 658, pp. 153-156, 2010.

[37] F. Ahnert and W. Heschel, "Multicomponent adsorption of butane, $\mathrm{NO}_{2}$ and $\mathrm{SO}_{2}$ on activated carbon," Adsorption Science \& Technology, vol. 20, no. 4, pp. 353-370, 2002. 

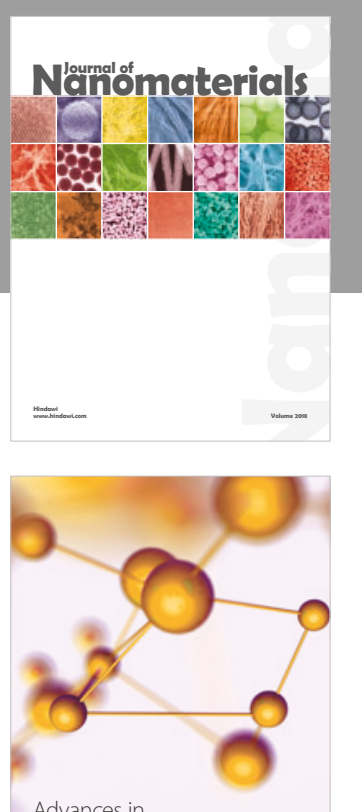

Physical Chemistry
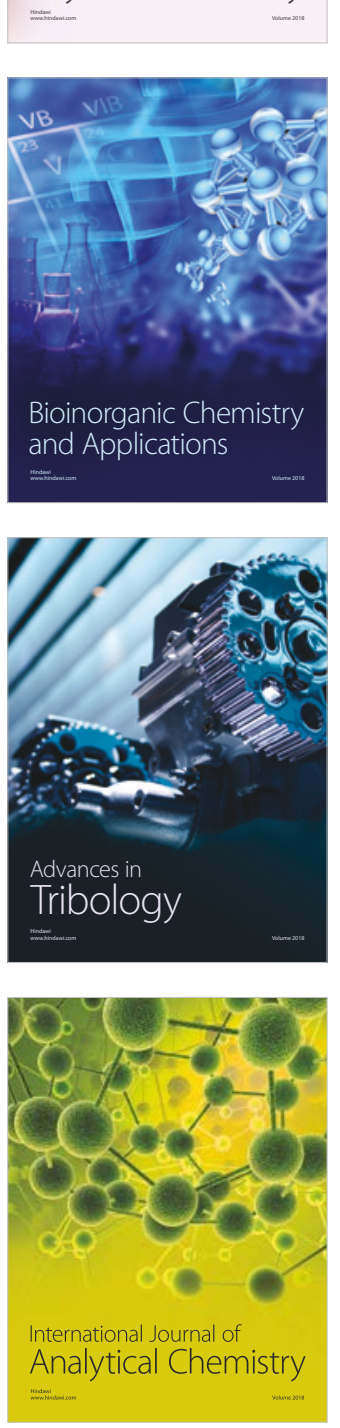

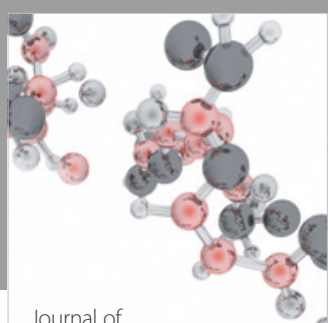

Analytical Methods

in Chemistry

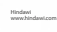

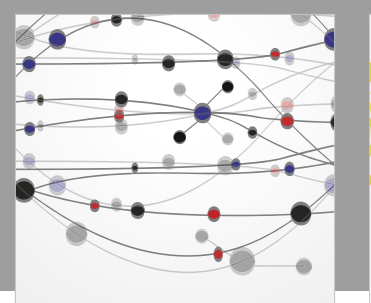

The Scientific World Journal

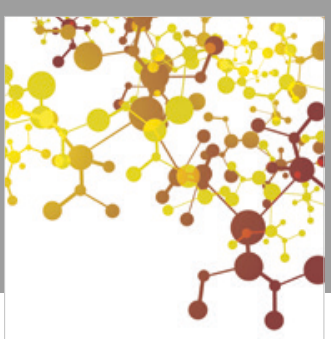

Journal of

Applied Chemistry
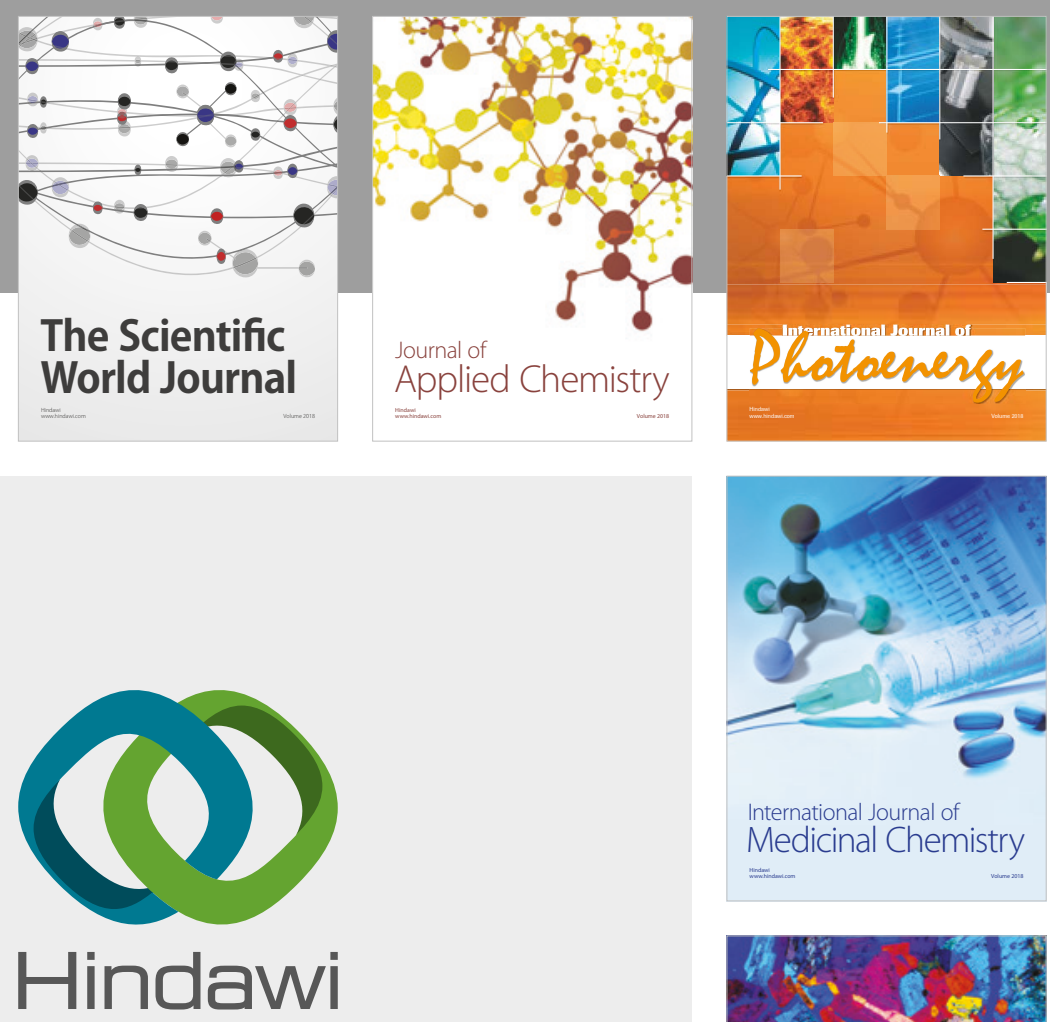

Submit your manuscripts at

www.hindawi.com
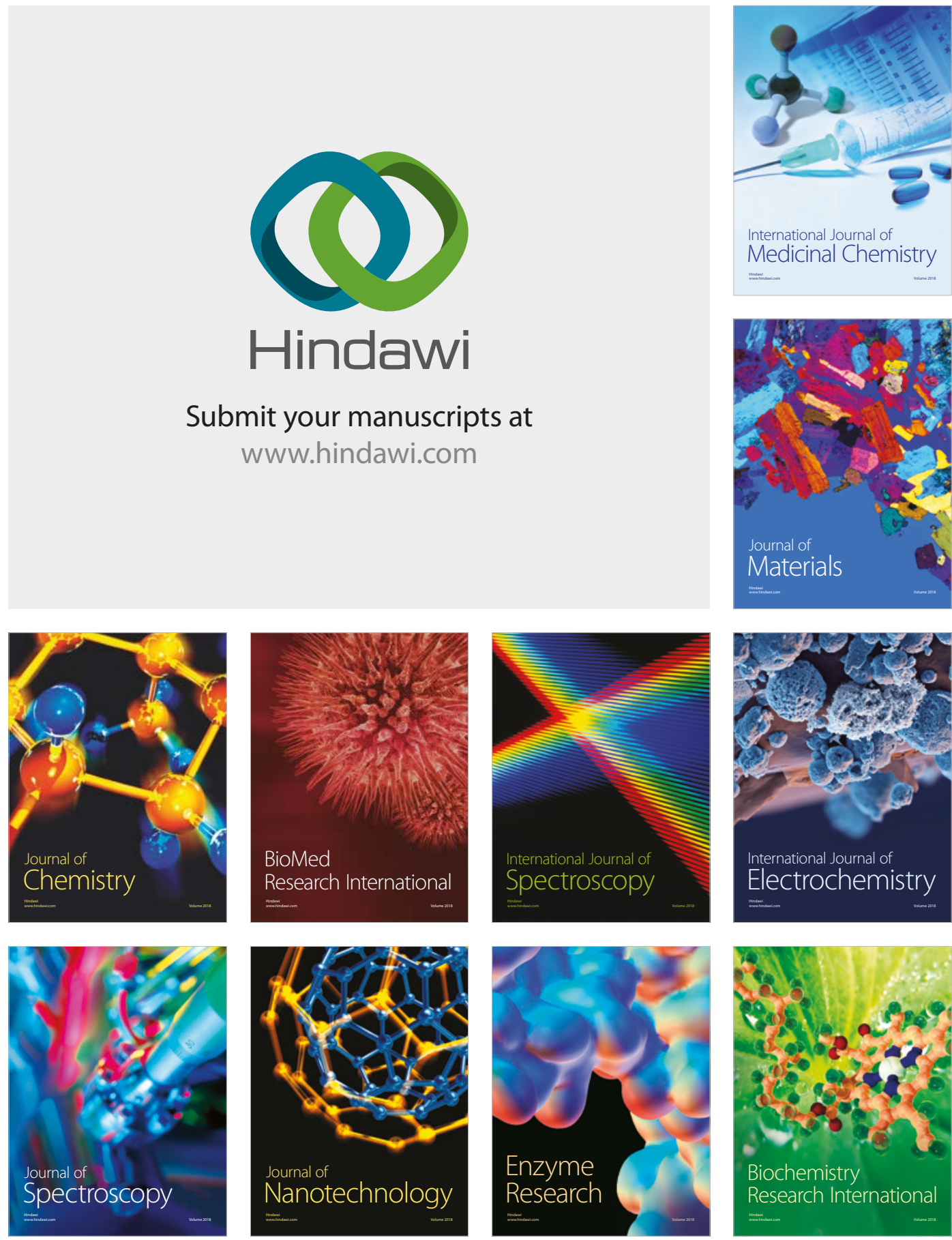
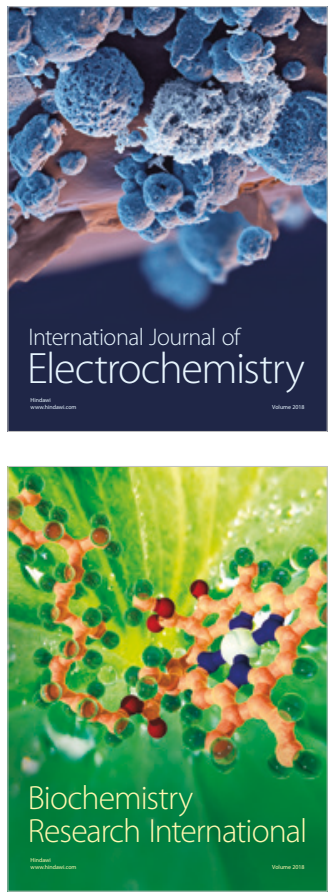